\title{
Effect of proline-rich polypeptide on various lines of tumour cells, normal bone marrow and giant- cell tumour stromal tissue
}

\author{
R. K. Chailakhyan, A. A. Galoyan', Yu. V. Gerasimov, E. V. Stepanova ${ }^{2}$,
} M. R. Chailakhyan, E. Sh. Solomko

N. F. Gamaleya Research Institute of Epidemiology and Microbiology, Rus. Acad. Med. Sci.

18, Gamalei Str., Moscow, Russian Federation, 123098

${ }^{1} \mathrm{H}$. Bunitian Institute of Biochemistry, NAS of Republic of Armenia

5/1, P. Sevak Str., Yerevan, Republic of Armenia, 0014

${ }^{2}$ N. N. Blokhin Russian Cancer Research Centre, Rus. Acad. Med. Sci.

24, Kashirskoye shosse, Moscow, Russian Federation, 115478

yugerasimov0521@yandex.ru

\begin{abstract}
The aim of the study was to assess the effect of proline-rich polypeptide (PRP) on bone marrow stromal stem cells in vivo and in vitro and on tumour cell lines. Methods. Isolation of giant-cell tumour $(G C T)$ stromal cells and obtaining these cell strains; obtaining normal bone marrow stromal cell strains; PRP administration to rats; bone marrow cell explantation into cultures; PRP addition to cell cultures. Results. Various routes and doses of PRP administration to rats increased the multipotent mesenchymal stromal cell (MMSC) concentration in the bone marrow. PRP addition to normal bone marrow MMSC cultures increased cell proliferation 1.52.5-fold, whereas PRP addition to GCT MMSC cultures inhibited cell proliferation 1.5-2-fold. Both proliferation inhibition and no PRP effect on proliferation were observed in tumour cell cultures. Conclusions. PRP administration to rats increased MMSC concentration in the normal bone marrow, and PRP addition to tissue cultures revealed opposite effects of PRP on cell proliferation.
\end{abstract}

Keywords: Proline-rich polypeptide (PRP), multipotent mesenchymal stromal cells (MMSC).

Introduction. The rapid progress of cell technologies in the recent decades was largely brought about by the discovery of bone marrow stromal stem cells (or multipotent mesenchymal stromal cells, MMSCs) [1] and their wide use in medical practice. Investigations of proline-rich polypeptide (PRP) effect on these cells are of great interest. PRP was first isolated by Galoyan et al. [2] from the neurosecretory granules of N. Supraopticus and N. Paraventricularis of the bovine pituitary, and it can have striking effects on various vital aspects of the living organism as previous studies have shown.

Materials and methods. To obtain human and rat normal bone marrow strains, we prepared a single-cell

(C) Institute of Molecular Biology and Genetics, NAS of Ukraine, 2011 suspension which was explanted into vials with a complete nutrient medium $\left(4 \cdot 10^{4}\right.$ cells $\left./ \mathrm{cm}^{2}\right)$. The cultivation was carried out in a $5 \% \mathrm{CO}_{2}$ atmosphere at $37{ }^{\circ} \mathrm{C}$. On Day 12-14 when discrete colonies of stromal fibroblasts were formed, the first passage was performed. The cultures were washed with saline and $0.25 \%$ trypsintreated. Then the cells were counted and transferred into a larger vial $\left(7-8 \cdot 10^{3}\right.$ cells $\left./ \mathrm{cm}^{2}\right)$. Giant-cell tumour (GCT) cells were isolated by trypsinization of minced tumour fragments $\left(1-1.5 \mathrm{~mm}^{3}\right)$ [3]. The cell suspension was explanted into vials with a complete nutrient medium $\left(5 \cdot 10^{6}\right.$ cells $/ \mathrm{cm}^{2}$ per vial $\left.80 \mathrm{~cm}^{2}\right)$. The passage was performed as described above. PRP effect on cell proliferation was studied using strains obtained by passage II-III. $3 \cdot 10^{4}$ cells of normal bone marrow were explanted into 


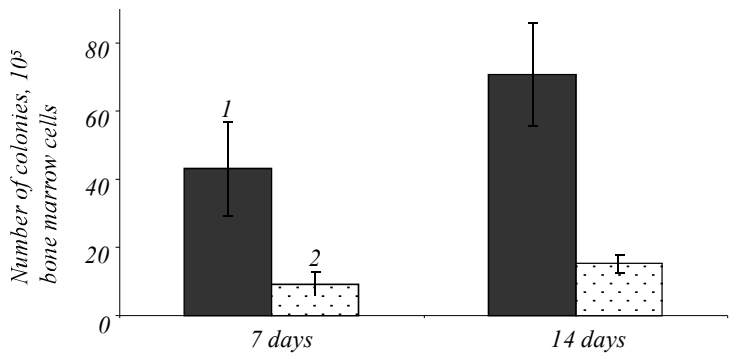

Fig. 1. Effectiveness of MMSC colony formation in rat bone marrow cultures after PRP $5 \mu \mathrm{g}$ i. m. administration: $1-5 \mu \mathrm{g} ; 2$ - control

each of 12 vials divided into 4 groups. PRP was added into the vials of each group: Gr. $1-1 \mu \mathrm{g} / \mathrm{vial}, \mathrm{Gr} .2-5 \mu \mathrm{g}$, Gr. $3-10 \mu \mathrm{g}$, and the vials of Gr. 4 were used as controls. The same experiment was used to study PRP effect on GCT stromal cells: $3 \cdot 10^{5}$ cells of each line were explanted into each of the vials where PRP $5 \mu \mathrm{g}$ was added.

To study PRP effect on MMSC concentration in the bone marrow, PRP $5 \mu \mathrm{g}$ (in $0.5 \mathrm{ml}$ of saline) was administered i. m. to rats. On Day 7 or 14 the rats were etherkilled and the tibias were isolated, bone marrow singlecell suspensions were prepared, and $5 \cdot 10^{5}$ cells were explanted into each of 4 vials $\left(25 \mathrm{~cm}^{2}\right)$ with a complete nutrient medium. The cultivation was carried out in a $5 \% \mathrm{CO}_{2}$ atmosphere at $37^{\circ} \mathrm{C}$. On Day $10-12$ the cultures were fixed and the grown colonies were counted.

Results and discussion. The clonal nature of colonies [4] allowed studying PRP effect on stromal stem cells in vivo. A single i. m. injection of PRP $5 \mu \mathrm{g}$ to rats resulted in a 5-9-fold increase of MMSC concentration in the bone marrow (Fig. 1). These findings are of great importance for cell technologists as they allow significant shortening of the time needed to grow the required number of cells for transplantation. In literature there is no information about any growth factors or other substances which could increase MMSC concentration in the bone marrow after administration into the living organism. Today PRP is the only substance which increases MMSC concentration in the bone marrow over 5-fold when administered i. $\mathrm{m}$. The stromal cells isolated from GCT do not differ in phenotype from MMSCs isolated from the normal bone marrow. Both populations of these cells show a high growth activity after their explantation into a tissue culture. PRP effect on the proliferation of these cells was studied using strains obtained by passage II-III. Vials containing $3 \cdot 10^{4}$ normal bone marrow cells were divided into 3 groups ( 3 vials in each group). PRP $0.2 \mu \mathrm{g} / \mathrm{ml}$ of medium was added into each vial in $\mathrm{Gr} .1,1$ $\mu \mathrm{g}$ - in Gr. 2, and $2 \mu \mathrm{g}$ - in Gr. 3. On Day 4 when the cell growth became almost confluent the cultivation was

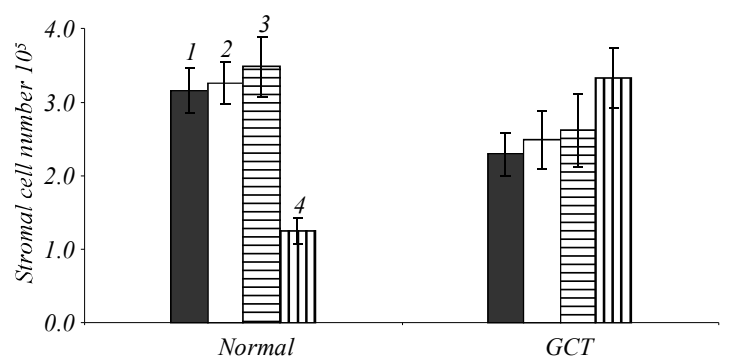

Fig. 2. PRP effect on stromal cell proliferation in human bone marrow cultures: $1-1 \mu \mathrm{g} ; 2-5 \mu \mathrm{g} ; 3-10 \mu \mathrm{g} ; 4$ - control

stopped. The results showed that the cell number in the experimental vials increased 1.5 -fold as compared to controls, irrespective of PRP concentration. A decreased number of explanted cells $\left(1.10^{4}\right)$ allowed prolongation of the cultivation period to 8 days. Prolonged PRP action on the cells (irrespective of PRP concentration) resulted in a 2-fold increase in the grown cell number as compared to that in 4-days culture (Fig. 2).

To study PRP effect on human GCT stromal cells, $1 \cdot 10^{4}$ and $3.3 \cdot 10^{3}$ cells were explanted into vials. The cultivation lasted 8 and 12 days respectively. PRP concentrations in the culture medium were the same. The grown cell number decreased 1.5-fold in the experimental vials as compared to controls (Fig. 2). The longer cultivation time (i. e. the increased length of PRP action on the proliferating cells) did not result in any additional inhibition of growth (Fig. 3). So our findings showed opposite effects of PRP on the stromal cells of normal and tumour tissues.

Inhibition of GCT stromal cell proliferation in vitro was the main determinant which guided our studies of PRP effect on other tumour cell lines: Mel. Kor - melanoma (skin cancer), SCOV-3 - ovarian cancer, and two lines of breast cancer - SKBR-3 and MCF-7. PRP $5 \mu \mathrm{g}$ was added into each vial containing $3 \cdot 10^{5}$ cells of these lines; the cell proliferation decreased 1.6-fold in the Mel. Kor line and 1.3-fold in the SKBR-3 line. PRP had practically no effect on the other tumour cell lines (Fig. 4).

Numerous groups of researchers are investigating the effect of various growth factors on MMSC proliferation and trying to increase MMSC colony formation by adding such growth factors to cultures. However their findings do not give a clear idea of the effect of certain growth factors on MMSCs [5]. This inconsistency may be accounted for by different methods of cell isolation, different nutrient media and different FBS concentrations in the media, etc. used by different researchers. Standard conditions are extremely important for all investigations of the effect of various growth factors. 


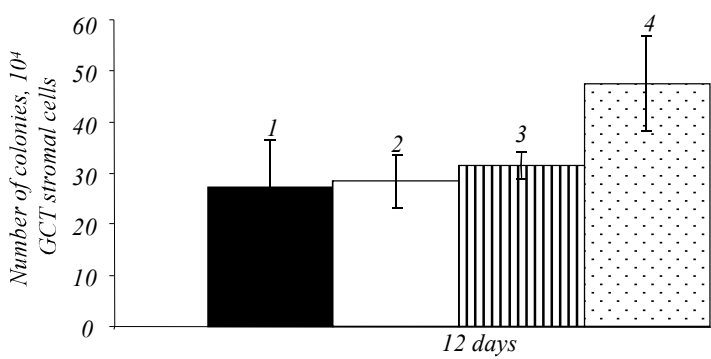

Fig. 3. PRP influens on the effectiveness of colony formation in human GCT cultures: $1-1 \mu \mathrm{g} ; 2-5 \mu \mathrm{g} ; 3-10 \mu \mathrm{g} ; 4$ - control

Conclusions. PRP $5 \mu \mathrm{g}$ i. m. administration to rats resulted in a 5-9-fold increase in MMSC concentration in the normal bone marrow. PRP added to cultures of stromal cells of normal bone marrow and GCT had opposite effects on cell proliferation. PRP decreased cell proliferation 1.5-fold in Mel. Kor and SKBR-3 cultures.

Р. К. Чайлахян, А. А. Галоян, Ю. В. Герасимов,

Є. В. Степанова, М. Р. Чайлахян, Е. Ш. Соломко

Дія багатого на пролін поліпептиду на різні лінії пухлинних клітин, стромальну тканину нормального кісткового мозку та гігантоклітинних пухлин

\section{Резюме}

Мета дослідження - вивчення впливу багатого на пролін поліпептиду (ПБП) на стовбурові клітини строми кісткового мозку іп vivo ma in vitro ілінї пухлинних клітин. Методи. Виділення стромальних клітин гігантоклітинної пухлнии (ГКП) $і$ отримання штамів ичи клітин, а також итамів стромальних клітин нормального кісткового мозку, введення ПБП щурам, експлантація в культуру кістковомозкових клітин, додавання ПБП у культури клітин. Результаты. Різні способи і дози введення ПБП щурам збільшують концентрачію мультипотентних мезенхі- мальних стромальних клітин (ММСК) у кістковому мозку. Додавання ПБП у культури ММСК нормального кісткового мозку призводить до зростання проліферативної активності клітин у 1,5-2,5 разу, внесення ПБПу культури ММСК ГКП інгібує проліферачію клітин у 1,5-2 разу. У культурах пухлинних клітин спостерігається як пригнічення пухлинних клітин, так і відсутність впливу поліпептиду на проліферачію. Висновки. Введення ПБП цурам підвищує концентрацію ММСК у нормальному кістковому мозку, а за додавання ПБП у культуру тканин виявлено його різноспрямовану дію на проліферацію клітин.

Ключові слова: багатий на пролін поліпептид, мультипотентні мезенхімальні стромальні клітини.

Р. К. Чайлахян, А. А. Галоян, Ю. В. Герасимов, Е. В. Степанова, М. Р. Чайлахян, Э. Ш. Соломко

Действие богатого пролином полипептида на различные линии опухолевых клеток, стромальную ткань нормального костного мозга и гигантоклеточной опухоли

Резюме

Цель исследования - изучение влияния богатого пролином поли пептида (ПБП) на стволовые клетки стромы костного мозга in

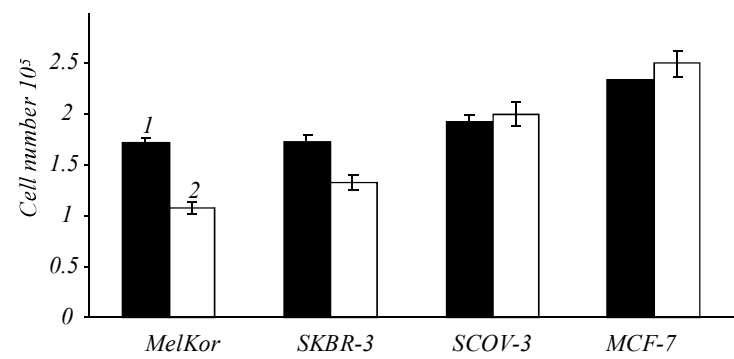

Fig. 4. PRP effeeffect on various tumour cell lines: 1 - control; 2 $5 \mu \mathrm{g}$

vivo $u$ in vitro $и$ линии опухолевых клеток. Методы. Выделение стромальных клеток гигантоклеточной опухоли (ГКО) и получение штаммов этих клеток, а также штаммов стромальных клеток нормального костного мозга, введение ПБП крысам, эксплантация в культуру костномозговых клеток, добавление ПБП в культуры клеток. Результаты. Различные способы и дозы введения ПБП крысам увеличивают кониентрацию мультипотентных мезенхимальных стромальных клеток (ММСК) в костном мозге. Добавление ПБП в культуры ММСК нормального костного мозга приводит к возрастанию пролиферативной активности клеток в 1,5-2,5 раза, внесение ПБП в культуры ММСК ГКО ингибирует пролиферацию клеток в 1,5-2 раза. В культурах опухолевых клеток наблюдалось как угнетение, так и отсутствие влияния полипептида на пролиферацию. Выводы. Введение ПБП крысам повымает кониентрачию ММСК в нормальном костном мозге, а при добавлении ПБП в культуру тканей выявлено его разнонаправленное действие на пролиферацию клеток.

Ключевые слова: богатый пролином полипептид, мультипотентные мезенхимальные стромальные клетки.

\section{REFERENCES}

1. Fridenstein A. J., Chailakhyan R. K., Lalykina K. S. The development of fibroblast colonies in monolayer cultures of guineapig bone marrow and spleen cells // Cell Tissue Kinet.-1970.-3, N 4.-P. 393-403.

2. Galoyan A. A. Neurochemistry of brain neuroendocrine immune system: Signal molecules // Neurochem. Res.-2000.-25, N 9/ 10.-P. 1343-1355.

3. Latsinik N. V., Sidorovich S. Yu., Fridenstein A. J. The influence of bone marrow trypsinization on the effectiveness of fibroblast colony formation in monolayer cultures // Bull. Exp. Biol. Med.-1981.- N 9.-P. 356-360.

4. Chailakhyan R. K., Fridenstein A. J., Vasilyev A. V. Clone formation in monolayer cultures of bone marrow // Bull. Exp. Biol. Med.-1970.- N 2.- P. 94-96.

5. Bianco P., Riminicci M., Gronthos S., Robey P. G. Bone marrow stromal stem cells: Nature, biology and potential applications // Stem Cells.-2001.-19, N 3.-P. 180-192.

UDC 577.112:576.3.5:616-002.182:616.018.46 Received 27.07.11 